\title{
ROLE OF THE EUROPEAN CENTRAL BANK IN COMBATING THE FINANCIAL CRISIS IN THE EUROPEAN UNION
}

\author{
Justyna Maliszewska-Nienartowicz \\ Amanda Witulska*
}

\begin{abstract}
This work presents the European Central Bank's role in eliminating economic crisis in the European Union. It contains roots and course of the financial slowdown in the eurozone. The Authors show competences of the institution before and its functions during the crisis. Finally, there was made an attempt to evaluate the effectiveness of the ECB monetary policy.
\end{abstract}

Key words: European Central Bank, eurozone, financial crisis, European Union, monetary policy, economic crisis, euro currency

\section{Introduction - causes and course of the EU euro area crisis}

As this article focuses on the role of the European Central Bank in combating the financial crisis in the EU, especially in the euro area, it is appropriate to specify at the beginning what the crisis consists in and, above all, indicate its main causes. There is no doubt that its emergence is

* Prof. dr hab. Justyna Maliszewska-Nienartowicz, Mgr Amanda Witulska, Faculty of Political Sciences and International Studies, Nicolaus Copernicus University 
a consequence of many factors, both external resulting from the functioning of the global economy and internal related to the weaknesses of the common currency area in the EU. "Numerous studies on the causes of the euro area crisis in 2010-2011 conclude unequivocally that next to fiscal policy errors and continued budget deficit (...), the repercussions of the 2007-2009 global financial and economic crisis, which had an adverse effect on the on functioning of global capital markets, including in Europe, were of primary importance." It is also noted that there was "a structural disequilibrium in the global economy, where some countries constantly showed a positive balance of payments and increased their reserves, whereas others had a negative balance, as a result of which they ran up debts."

Some studies emphasise, however, that whilst the global financial and economic crisis constituted a spark that set off the situation in the euro area, it was not the direct source of the problems there; ${ }^{3}$ it accelerated the development of negative events which, even if at a later time, would have occurred anyway. Indeed, on the one hand, there are many imperfections in the structure of the common currency area in the EU, and on the other, some countries are not prepared to cope with the challenges resulting from functioning in the euro area. ${ }^{4}$ Hence the view that "the root cause of the crisis, which contributed to the emergence of subsequent causes, was the euro area's failure to meet the basic conditions for the functioning of the optimum currency area." ${ }^{5}$

As a result, the following can be considered as the direct causes of the crisis:

1. considerable diversity of the development levels and economic structures of the euro area member states;

1 See e.g. E. Cziomer, Polityczno-prawne aspekty kryzysu zadłużenia strefy euro Unii Europejskiej [Political and Legal aspects of the debt crisis of the Eurozone], "Annales Universitatis Maria Curie-Skłodowska” 2012, vol. XIX, at p. 13. Similarly, J. Kraciuk, Kryzys finansowy strefy euro [Financial crisis of the Eurozone], "Optimum. Studia ekonomiczne" 2013, no. 4, at p. 129.

2 J. Kraciuk, op. cit., at p. 129.

3 NBP, Kryzys w strefie euro. Przyczyny, przebieg i perspektywy jego rozwiq̨zania [Crisis of the Eurozone. Its reasons, course, and perspectives of its solution], Warsaw 2013, at p. 9.

4 Ibidem.

5 N. Białek, Przyczyny wybuchu kryzysu strefy euro: rola polityki monetarnej USA oraz Europejskiego Banku Centralnego [Reasons of the Eurozone crisis breakout: the role of the monetary policy of the U.S. and European Central Bank], "WSIiZ Working Paper Series" 2014, no 1 , at p. 3. 
2. low ability of some countries to cope with economic shocks, related to the absence of appropriate regulations and institutions or low competitiveness;

3. ineffectiveness of the mechanisms enforcing a responsible fiscal policy, including market mechanisms;

4. lack of sufficient supervision over the financial sector;

5. lack of crisis management mechanisms and of financial support for the most threatened euro area countries. ${ }^{6}$

The first signals of the financial crisis in the European Union appeared in the summer of 2007, in response to news coming from the financial markets in the United States. ${ }^{7}$ On 15 September 2008 America's fourth largest investment bank - Lehman Brothers collapsed, which decidedly exacerbated the nascent banking crisis. ${ }^{8}$ Due to strong capital and transactional links and an elaborate exchange of goods with the European Union, the crisis spread into this area and other parts of the world. ${ }^{9}$ It affected the euro area in a particular manner.

This explains why two phases are usually distinguished in relation to the crisis in the European Union. The first falls in 2007-2009 and the second is believed to have begun in 2010, when financial bankruptcy spread in successive European countries. In both those periods the European Central Bank undertook varied actions, trying to fit them to the changing situation in the financial markets. The purpose of this article is not only to present the Bank's anti-crisis policy, but also to attempt to evaluate it. Hence it is essential to indicate first of all what competence was vested in the Bank by the euro area member states in the treaty provisions, including those contained in the Statute of the European System of Central Banks and of the European Central Bank. In conclusion, changes to the ECB's functioning introduced in the aftermath of the crisis and the proposals formulated in the literature on the subject with regard to a more precise

6 NBP, op. cit., at p. 10.

7 J. Kozłowska, Polityka Europejskiego Banku Centralnego w dobie kryzysu finansowego [Policy of the European Central Bank at a time of financial crisis], "Zeszyty Naukowe Firma i Rynek" 2015, no 1, p. 25.

8 P. Albiński, Kryzysy i polityka stabilizacyjna w Unii Europejskiej [Crises and the stability policy in the European Union], [in:] P. Albiński (ed.), 'Kryzys a polityka stabilizacyjna w Unii Europejskiej' [Crisis and the stability policy in the European Union], Oficyna Wydawnicza SGH, Warszawa 2014, at p. 20.

9 Ibidem. 
specification of the ECB's tasks and its position in the EU institutional system will be considered.

\section{Competence of the European Central Bank in the euro area in light of the provisions of the TFEU and the ECB Statute}

The fundamental functions of the Bank, defined in the Treaty on the Functioning of the European Union (TFEU) ${ }^{10}$ and specified in the ECB Statute ${ }^{11}$, include above all: conducting monetary policy, maintaining price stability and issuing euro as well as protecting its purchasing power. The ECB is the central bank for the common currency and has the exclusive right to authorise the issue of euro banknotes. ${ }^{12}$ Once the euro is introduced in all EU member states, the ECB will automatically become the central bank for the entire EU.

Monetary operations and functions performed by the European System of Central Banks (ESCB), including by the ECB, which is the core of the system, are set forth in chapter IV of the statute. First of all, both the ECB and national central banks were granted the right to perform operations on financial markets and properly secured loan operations on terms and conditions defined by the ECB itself. ${ }^{13}$ In order to conduct their operations, the ECB and national central banks may open bank accounts for credit institutions, public authorities and other market participants, and accept assets, including dematerialised securities, on current account as collateral. ${ }^{14}$

The Treaty considers the already mentioned price stability as the primary objective of the ESCB, hence maintaining prices at an appropriate level constitutes the key task for the entire Eurosystem. Monetary policy orientated this way secures improved economic prospects

10 Treaty on the Functioning of the European Union, O.J. C 326, 26.10.2012, p. 47-390.

11 Protocol (No. 4) on the Statute of the European System of Central Banks and of the European Central Bank,O.J. C 202, 7.6.2016, p. 230-250 .

12 J. Barcz, M. Górka, A. Wyrozumska, Instytucje i prawo UE [Institutions and law of the European Union], 3rd ed., LexisNexis, Warsaw 2012, p. 204.

13 Art. 18 of the Protocol (No. 4).

14 Ibidem. 
and increased living standards of the citizens of Eurosystem member states. ${ }^{15}$ Within the monetary policy, the Eurosystem has full control over the monetary base, which enables it to influence both the conditions prevailing on the monetary market and interest rates. Price stability guarantees the possibility of economic growth and increased employment for the euro area.

An important task of the ECB, closely correlated to monetary policy, is to support the effective operation of payment systems constituting a fundamental element of financial markets infrastructure. ${ }^{16}$ Liquidity of payments on the internal market is conducive to the appropriate management of the common currency, which is why it is so important that both the ECB and national central banks create convenient conditions for the functioning of payment systems. The ESCB was also authorised to conduct foreign currency operations, that is to intervene in forex markets. Therefore, it should properly manage foreign currency reserves of member states. These reserves (to be exact, their determined part) are provided to the Bank only by states that belong to the Eurosystem. The size of reserves provided depends on the given country's share in ECB equity. ${ }^{17}$ To calculate the contributions of individual member states, the given country's share in the total population and GDP of the European Union is taken into account. The ECB adjusts the size of the contributions systematically every five years and after each enlargement of the EU.

Due to the fact that the ECB has the right to maintain and manage currency reserves of member states, their central banks obtain from the Bank debt claims equivalent to their contribution. Article 31 of the Statute also authorises them to perform operations as part of their liabilities to international organisations, nevertheless, "all other operations in foreign reserve assets remaining with the national central banks (...) and Member States' transactions with their foreign exchange working balances shall, above a certain limit (...), be subject to approval by the ECB in order to ensure consistency with the exchange rate and monetary policies of the Union." 18

15 Cf. H.K. Scheller, The European Central Bank. History, Role and Functions. Second revised edition, European Central Bank, Frankfurt am Main 2006, at p. 45.

16 Cf. H. Gronkiewicz-Waltz, Europejska Unia Gospodarcza i Walutowa [European Economic and Currency Union], LexisNexis, Warsaw 2010, at p. 137-138.

17 Ibidem.

18 Art. 31.2 of the Protocol (No. 4). 
In connection with conducting monetary policy, the ECB is obliged to submit annual statements on the activities of the entire ESCB for the previous and current year to the European Parliament, European Commission, Council of the European Union and the European Council. ${ }^{19}$ The ECB also has advisory functions - it is consulted on all matters within its remit and may also issue opinions within this scope. Euro area member states should seek the Bank's opinion on draft legislation on matters concerning banking, payment systems and means of payment, finances, national central banks and other financial institutions which influence the stability of monetary markets. ${ }^{20}$

Pursuant to art. 132 TFEE, the ECB also approves regulations, makes decisions and issues recommendations. ${ }^{21}$ The regulations apply directly in all countries of the euro area and are binding in total. Their general reach means that they may concern an unlimited number of entities and cases. ${ }^{22}$ The decisions are also legislative acts binding in total. They can be addressed to a euro area member state as well as to any natural or legal person. In turn, the recommendations - as the previously mentioned opinions - are not of a binding nature. Nevertheless, they constitute an instrument allowing the ECB to initiate desirable actions in the field of monetary policy as well as propose legislative initiatives in EU law regulating the actions within its competence. ${ }^{23}$ In the event of non-compliance with the acts issued by the $\mathrm{ECB}$, the bank has the right to impose fines and periodic pecuniary penalties on the enterprises concerned.

The ECB is tasked with conducting active international co-operation. It may participate in international currency institutions and grant consent to such participation by individual central banks. In co-operation with the EU institutions, bodies and organisational units, as well as the competent authorities of individual states or international organisations, and with the help of national central banks, the ECB collects necessary, up-to-date statistics. ${ }^{24}$ They are published, inter alia, in the Monthly Bulletin issued as part of the Bank's reporting obligations. Moreover, in addition to annual

19 Cf. J. Maliszewska-Nienartowicz, System instytucjonalny i prawny Unii Europejskiej [Institutional and legal system of the European Union], Dom Organizatora, Torun 2010, at p. 189.

20 Cf. H.K. Scheller, op. cit., at p. 73.

21 Cf. art. 132 TFEU.

22 Cf. H.K. Scheller, op. cit., at p. 70.

23 H.K. Scheller, op. cit., at p. 71.

24 Art. 4 and art. 5 of the Protocol (No 4). 
reports on the activities of the ESCB, the ECB also publishes consolidated financial statements and detailed academic studies. ${ }^{25}$

In the performance of all the aforementioned functions, the fundamental principle by which the ESCB is to be guided is the independence vested in it by the treaty. Both the ECB and individual central banks of the EU member states are strictly prohibited from seeking and accepting any instructions whatsoever from the EU bodies and institutions, member state governments or other institutions which might influence the decisions made by the ECB. ${ }^{26}$

\section{Actions undertaken by the ECB in connection with the euro area crisis}

\subsection{First phase of the crisis}

In the first phase of the crisis the ECB pursued a two-pronged monetary policy in the euro area. On the one hand, it systematically reduced interest rates (although in comparison with other global banks it delayed for a long time its decision to reduce the rates), on the other, it intensified its activities in the field of open market transactions (prior to the crisis it limited itself to using only the main refinancing operations). ${ }^{27}$ From mid-2007 it increasingly frequently performed additional open market transactions - apart from the main refinancing operations (MRO), it introduced longer-time refinancing operations (LTRO). ${ }^{28}$ Thereby, the ECB wanted to minimise the effects of the panic unleashed by the crisis in the USA, reduce uncertainty in the interbank market and increase control over the level of inflation in the euro area.

The existence of the common currency system entails the risk stemming from potentially irresponsible policies of member states.

25 Cf. K. Janowski, Europejski Bank Centralny (EBC) [European Central Bank], http:// uniaeuropejska.org/europejski-bank-centralny-ebc/ (accessed 6.10.2017).

${ }^{26}$ Cf. K. Szeląg, Integracja walutowa $w$ Europie Zachodniej w okresie powojennym [Currency integration in the Western Europe in the post-war era], "Materiały i Studia" 2003, no 166 , at p. 28.

${ }_{27}$ Cf. J. Kozłowska, op. cit., at p. 21 and at p. 25.

${ }_{28}$ Cf. Open market operations, https://www.ecb.europa.eu/mopo/implement/omo/ html/index.en.html (accessed 19.11.2017). 
A classic example in this context is Greece and its reckless fiscal policy, which eventually led the country to bankruptcy. "The greedy state increased taxes and the Greeks avoided paying them. Hence the financial deficit at 6-10 per cent of GDP, which resulted in public debt growth in the 12 years from its accession to the Union from 22 per cent to 98 per cent of GDP in 1993." ${ }^{29}$ A guarantee of financial support from the ECB and the International Monetary Fund (IMF) allowed the Greek government to increase spending systematically. Greece started incurring debt at the same pace as Germany, which pursued a prudent fiscal policy and had a positive balance of trade. ${ }^{30}$ It resulted also from the fact that foreign investors treated Greece as creditworthy as Germany and lent it money as cheaply as they did to Germany. This led to a situation where per capita income in Greece in 2009 was as much as 94 per cent of the EU average. ${ }^{31}$ Unfortunately, the Greeks were forced to pay with the crisis for having lived beyond their means.

Structural problems of Greek public finances considerably weakened the state's ability to service debt. As a result, there was a sudden growth in the profitability of Greek bonds, leading to the so-called debt spiral and contagion effect, threatening other countries of the euro area. ${ }^{32}$ In 2009 the ECB abandoned all rating requirements for Greek bonds, which cast doubts on its independence. "The ECB was to accept Greek bonds unconditionally. It abandoned its hitherto attitude and started pursuing political plans, which took away its credibility. ${ }^{33}$ " Unfortunately, the specific nature of the euro area, characterised by mutual interdependence of member states, causes the crisis of one member to be felt by the others. Not wanting to allow the Greek example to spread to other countries, in the first phase

29 T. Jóźwik, Grecja - tragedia trwa [Greece - the tragedy continues], https://www. forbes.pl/gielda/jak-doszlo-do-kryzysu-gospodarczego-w-grecji/vwxh3n4 (accessed 26.9.2017).

30 Cf. P. Bagus, Tragedia euro [The tragedy of Euro], Ludwig von Mises Institute, Alabama 2012, at p. 95.

31 Cf. T. Jóźwik, Grecja - tragedia trwa [Greece - the tragedy continues], https://www. forbes.pl/gielda/jak-doszlo-do-kryzysu-gospodarczego-w-grecji/vwxh3n4 (accessed 26.9.2017).

32 Cf. Ministry of Finance, Kryzys grecki-geneza ikonsekwencje. Dokument uzupetniajacy do ram strategicznych Narodowego Planu Wprowadzenia Euro [The Greek crisis - genesis and consequences. Supplementary document to the strategic ramifications National Plan for the Euro Introduction], Warsaw 2010, p. 14.

33 P. Bagus, op. cit., at p. 105. 
of the crisis representatives of the currency union established temporary mechanisms of financial assistance ${ }^{34}$ which were subsequently replaced with the European Stability Mechanism (ESM). ${ }^{35}$

However, the ESM did not become a mechanism well-equipped enough to prevent recession in other euro area countries. In connection with their considerable budgetary problems, also Portugal, Italy, Ireland and Spain began to be counted next to Greece among states threatened with bankruptcy. ${ }^{36}$ The policy conducted by the ECB from 2005 not only failed to protect the aforementioned countries from the crisis, but also might have even contributed to the development of a crisis situation in them. It resulted from a complete reversal of the direction of the ECB's monetary policy: from loose to clearly tighter. In the period of the culmination of the crisis in the USA, the Bank began to raise interest rates sharply, which was a measure PIIGS were unable to cope with.

\subsection{Second phase of the crisis}

The ECB, in an effort to influence directly the public debt market of countries at risk and help them in overcoming the problem of their fiscal difficulties, launched in 2010 the so-called Securities Market Programme (SMP). ${ }^{37}$ Its purpose was to ensure liquidity of dysfunctional segments of the debt securities market by purchasing bonds of those euro area countries which were characterised by the lowest level of trust among investors.

Direct purchases of bonds by the ECB marked a turning point in the Bank's monetary policy - previously it had accepted bonds only as collateral in order to secure loans. What is more, the debt securities it bought were characterised by high risk, therefore, the Bank's risk of incurring

34 European Financial Stabilisation Mechanism (EFSM) and European Financial Stability Facility (EFSF). See e,g, A. Wancio, Europejskie Mechanizmy Stabilności Finansowejgwarancja stabilności strefy euro czy gra na zwłokę? [European mechanisms for the financial stability - warranty of the Eurozone stability or an attempt to buy time?], "Wspólnoty Europejskie" 2011, no 3, at pp. 48-49.

${ }^{35}$ It will be discussed more extensively in section 6 of this study.

36 The acronym PIIGS (Portugal, Italy, Ireland, Greece, Spain) was coined to refer to this group of countries.

37 Cf. European Central Bank, Monthly Bulletin. June 2010, Frankfurt am Main 2010, p. 24. 
losses on its own assets became real. ${ }^{38}$ In spite of that the balance sheet of the ECB in 2010-2011 was relatively stable, which allowed it to raise interest rates in 2011. Unfortunately, the Bank was too hasty in making this decision - banking systems of some euro area countries were unable to cope with such a rapid change of the ECB's policy, which is why already at the end of 2011 interest rates rises were reversed and the rates returned to a record low level. ${ }^{39}$

At the same time, the longer-time refinancing operations (LTRO) programme was relaunched and within its framework the ECB provided European banks with low-interest loans of the total value of EUR 1tr. ${ }^{40}$ In subsequent years, interest rates continued to decrease and the EBC continued to purchase bonds in an effort to break away from the pre-crisis model of monetary policy (focused on maintaining price stability) and favour a policy mindful of the fiscal condition of the euro area countries. In order to improve their economic situation and the condition of their public finances, the Fiscal Compact was signed in March 2012, tightening the rules of conducting fiscal policy in the euro area. According to numerous analysts, it is the excessive imbalance in the private and public sectors that constitutes the main source of the current problems in the euro area. ${ }^{41}$

In September 2012 the ECB proposed a new programme of purchasing government bonds from the secondary market - outright monetary transactions (OMT). "The commencement of purchasing must be preceded with an application for assistance under the relevant EFSF (European Financial Stability Facility) or ESM (European Stabilisation Mechanism) programme." ${ }^{42}$ The OMTs differ from the SMP by the fact that in the event of bankruptcy of a euro area country, the debt held by the ECB will be subject to restructuring. Generally, the programme is aimed at eliminating disturbances to the monetary policy transmission mechanism and at safeguarding the singleness of the monetary policy. However, the programme gave rise to doubts concerning infringements

38 Cf. M. Benedyk, Polityka pieniężna Europejskiego Banku Centralnego w latach 1999-2013 [Currency policy of the European Central Bank between 1999 and 2013], "Ekonomia - Wrocław Economic Review" 2013, no 19, at p. 24.

39 Ibidem.

40 Cf. NBP, op. cit., at p. 24.

41 NBP, op. cit., at p. 25.

${ }^{42}$ Cf. M. Kapuściński, EBC: Nowy plan ratunkowy nie jest drukowaniem pieniądza [New rescue plan means not printing money], https://www.obserwatorfinansowy.pl/ tematyka/rynki-finansowe/ebc-skupi-obligacje-warunkowo/ (accessed 30.11.2017). 
of treaty provisions pertaining to both the scope of the ECB's competence and the prohibition of direct funding of member states by the Bank and national central banks. ${ }^{43}$

In 2013-2014, in connection with a growing deflation pressure and the weakening business cycle of the entire euro area, the ECB consistently reduced interest rates. ${ }^{44}$ Deposit, refinancing and loan rates reached their historical results - in September 2014 they were at $-0.2 \%, 0.05 \%$ and $0.3 \%$, respectively. ${ }^{45}$ By acting through the channel of interest rates, the $\mathrm{ECB}$, which was grappling with a crisis of trust, wanted to stimulate the liquidity of the interbank sector - unfortunately, to no avail. The scale of the crisis proved to be too large, therefore, the Bank was forced to undertake the next, non-standard actions.

In January 2015 Mario Draghi announced the beginning of the quantitative easing (QE) programme, ${ }^{46}$ consisting in the further purchasing of government bonds or other securities by the ECB in order to increase the supply of money by the growth in the balance sheet of the central bank. Initially, the QE was to last until September 2016 and its value was set at the level of EUR 60bn monthly; however, in view of the forecasts and inflation expectations, the duration of the programme was extended to March 2017 and the value of assets purchased increased to EUR 80bn. ${ }^{47}$

The use by the ECB of non-standard means of monetary policy and the maintenance of low interest rates has a fundamental impact on the improvement in the conditions of financing of the real economy. In this situation, the ECB intends to continue to consistently maintain interest rates at a low level and continue to purchase assets. In March 2017 Mario Draghi once again extended the term of asset purchases under the $\mathrm{QE}$ programme - from April to December 2017 it was to amount to EUR 60bn monthly. ${ }^{48}$ At a meeting of the ECB Governing Council in October 2017 it

43 See comments in section 4 of this article.

44 Cf. M. Ciepłucha, E. Zientalak, Rola EBC w walce z kryzysem strefy euro ze szczególnym uwzględnieniem kryzysu zadłużeniowego $w$ Grecji [The role of ECB in the fight against the Eurozone crisis, with special emphasizes on the debt crisis in Greece], Wydział Ekonomiczno-Socjologiczny Uniwersytetu Łódzkiego, Łódź 2016, at p. 27.

45 Ibidem.

46 Cf. G. Claeys, A. Leandro, The European Central Bank's Quantitative Easing Programme: Limits and Risks, "Bruegel Policy Contribution" 2016, no 4, at p. 2.

${ }_{47}$ Cf. M. Ciepłucha, E. Zientalak, op. cit., at p. 32.

48 Cf. Europejski Bank Centralny, "Biuletyn Ekonomiczny. Przegląd sytuacji finansowo-gospodarczej” 2017, no 2, at pp. 4-5. 
was decided quantitative easing would be extended once more, however, with a simultaneous reduction of the level of asset purchasing to EUR $30 \mathrm{bn} .{ }^{49}$ Currently, the QE is being phased out, although the Bank does not exclude the possibility of another extension of the programme until the ECB ascertains a sustained convergence of the inflation path with the assumed inflation target. As of today, the last purchases of assets are planned for September 2018. ${ }^{50}$

It is worth adding here that the quantitative easing programme in the USA already expired on October 2014. Should the ECB decide to further maintain a high level of asset purchasing and reduce interest rates, with the simultaneous upward movement of the rates continued by the FED, the "divergence, unprecedented in the latest history, of the policies of the world's major central banks" ${ }^{51}$ might deepen considerably. As of today, the QE effects are not clearly noticeable, mainly due to the shortterm nature of the programme implementation. However, opponents of this type of solutions reproach the ECB for creating a situation that threatens the financial market stability, pumping up a speculative bubble, constraining competition in the markets of some countries, and increasing income disproportions. ${ }^{52}$

49 Cf. M. Żóławiński, EBC podjął decyzję w sprawie QE. 30 mld euro miesięcznie do września 2018 r. [ECB took its decision on QR. 30 bln euro monthly until September 2018], https://www.bankier.pl/wiadomosc/EBC-podjal-decyzje-w-sprawie-QE-30-mldeuro-miesiecznie-do-wrzesnia-2018-r-7551988.html (accessed 26.10.2017).

50 Cf. J. Wilk, Jest decyzja w sprawie QE - EBC wyłączy połowę drukarek [Decision on QE - ECB will turn off half of its printers], https://www.fxmag.pl/artykul/jest-decyzjaw-sprawie-qe-ebc-wylaczy-polowe-drukarek (accessed 26.10.2017).

${ }_{51}$ M. Żóławiński, EBC przed najważniejszq decyzją roku. Co dalej z QE? [ECB before the most important decision of this year - what next with QE?], https://www.bankier. pl/wiadomosc/EBC-przed-najwazniejsza-decyzja-roku-Co-dalej-z-QE-7551655.html (accessed 26.10.2017).

52 Cf. K. Kil, R. Ślusarczyk, Dylematy polityki pieniężnej Europejskiego Banku Centralnego z perspektywy 2015 roku [Dilemmas of monetary policy of the European Central Bank: a 2015 perspective], [in:] S. Owsiak (ed.), 'Mechanizmy funkcjonowania strefy euro, wybrane problemy VI' [Mechanisms of functioning of the Eurozone. Selected issues VI], Krakowska Szkoła Biznesu Uniwersytetu Ekonomicznego w Krakowie, Kraków 2015, at p. 35. 


\section{An attempt to evaluate the ECB's actions}

An evaluation of the actions undertaken by the European Central Bank in response to the euro area crisis may be made from two perspectives. Firstly, a typically economic one, taking into account the effectiveness of the instruments applied by this institution. Secondly, from a legal perspective, which involves an attempt to answer the question whether the ECB, by undertaking unconventional actions, exceeds the boundaries of the competence vested in it by the treaty provisions, including the ones contained in the statue of the ESCB and of the ECB. With regard to the effectiveness of the actions undertaken by the Bank, it should be noted than an evaluation in this respect is not unambiguous. On the one hand, the opinion is voiced that the ECB's actions, especially in the first stage of the crisis, "contributed to a significant stabilisation of the situation in the interbank market. Interest rates in the monetary market were at a level similar to that of the ECB base rates, which indicated a correct transmission of monetary policy under crisis conditions. Furthermore, the anti-crisis measures prevented a collapse of loan action of banks, positively stimulating economic activity in the euro area." ${ }^{53}$ It is emphasised that the monetary policy of the ECB differed from the policies of other central banks, since it was more balanced - asset purchasing programmes conducted by this institution were incomparably smaller (no massive purchasing), their consequence was not any growth in money supply, and their implementation was explained not as any additional monetary easing but as a measure supporting the conventional monetary policy. ${ }^{54}$ However, despite its more conservative nature, the attitude of the ECB can hardly be called passive, and the Bank's actions can hardly be reproached for a complete lack of effectiveness - its tactic proved to be effective if the panic in financial markets was successfully neutralised. ${ }^{55}$

53 K. Sum, Antykryzysowe działania Europejskiego Banku Centralnego - przyczyny, przebieg i skutki w poszczególnych fazach kryzysu [Anti-crisis measures of the European Central Bank - reasons, conduct, and consequences in different phases of the crisis], “Zeszyty naukowe Wyższej Szkoły Bankowej we Wrocławiu” 2016, no 1, at pp. 51-52.

${ }^{54}$ For this opinion, see e.g. M. Pronobis, Czy Europejski Bank Centralny uratuje strefe euro? [Will the European Central Bank save the Eurozone?], "Analiza Natolińska" 2013, no 9, at p.10.

55 M. Pronobis, op. cit., at pp. 10-11. 
On the other hand, the anti-crisis policy pursued by this institution is criticised - its excessively cautious nature is pointed out as well as the fact that it served more to stabilise financial markets and to reduce costs of public debt servicing by individual governments than to stimulate economic growth. ${ }^{56}$ Some representatives of the doctrine reproach the Bank for having assumed the role of a lender of last resort - witness the reduction of interest rates and considerably increased activity of lending to the banking sectors in the countries affected by the debt crisis. ${ }^{57}$ In this context, however, it is stressed in the literature that in the face of the financial crisis, standard monetary operations would not have been a sufficient means of conducting an effective monetary policy. ${ }^{58}$ Some economists also indicate the negative effect of the ECB's anti-crisis actions on the external value of the euro (five countries of the euro area, especially Italy, Portugal and Spain, saw a depreciation of the euro to the US dollar). ${ }^{59}$ Nevertheless, one of the most serious charges levelled against the ECB's actions is the one that the ECB encouraged the most indebted countries to a moral gamble consisting in incurring more debt at the expense of the entire euro area. ${ }^{60}$ This argument can hardly be challenged. All those quite diverse evaluations of the Bank's anti-crisis policy in terms of its effectiveness or possibly certain negative outcomes may not, however, disregard the fact that the policy contributed to the stabilisation of financial markets, where the growing panic was successfully contained. The ECB also achieved its primary objective of preserving the euro area.

Some commentators of the Bank's actions emphasise additionally that "the Bank significantly increased the scope of its power in the euro area, overstepped its mandate, and even breached the treaty provisions determining its competence." ${ }^{\prime 1}$ In the context of answering the question whether the ECB, by engaging in non-conventional actions, exceeded the boundaries of the competence vested in it by the treaty regulations,

56 T. Grosse, O trzech kryteriach oceny legitymacji Europejskiego Banku Centralnego w okresie kryzysu [About three criteria of assessment of the legitimation of the European Central Bank at a time of crisis], "Myśl Ekonomiczna i Polityczna" 2013, no 2, at p. 118.

57 See K. Sum, op. cit., at p. 50 and the literature referred to therein.

58 Ibidem.

59 S. Eichler, Financial crisis risk, ECB "non-standard"measures and the external value of the euro, "The Quarterly Review of Economics and Finance" 2012, vol. 52, at p. 264.

60 See e.g. P. De Grauwe, The European Central Bank as Lender of Last Resort in the Government Bond Markets, "CESifo Economic Studies” 2013, vol. 59, no. 3, at p. 526.

61 T. Grosse, op. cit., at p. 111. 
including the provisions contained in the statute of the ESCB and of the ECB, the exceptional nature of the situation in the euro area should be noted above all. It is beyond doubt that "a bankruptcy of any of the euro area state would have had far-reaching implications for the ECB. Such a bankruptcy, by undermining the sense of any further currency integration, would have led to a sudden drop in the euro value, thereby making it impossible to achieve the basic goal of monetary policy, that is to maintain a stable level of prices." 62 The ECB's actions were not of a systemic nature, that is they did not introduce the required institutional reforms, yet they allowed politicians to gain the time necessary to undertake systemic reforms. ${ }^{63}$ It seems that this exceptionality of the situation in the euro area legitimises to a certain extent the Bank's moves, even if some of them bypassed the applicable EU regulations.

It was probably why the Court of Justice adopted a less restrictive interpretation of the regulations pertaining to economic and monetary policies and the ECB's competence in those areas in its judgement of 16 June 2015 in the case Peter Gauweiler and Others v Deutscher Bundestag. ${ }^{64}$ It concerned the compliance of the European Central Bank's OMT decision with EU law. It is worth noting that the applicant in the main proceedings argued, firstly, that the decisions jointly constituted an act of ultra vires, since they were not within the ECB's mandate and were contradictory with art. 123 TFEU, and, secondly, that the decisions breached the principle of democracy enshrined in the Grundgesetz (German constitution), thus limiting German constitutional identity. As a result, the Federal Constitutional Tribunal suspended the proceedings and addressed to the Court of Justice several prejudicial questions concerning the compliance of the ECB's OMT decision with a few treaty provisions -art. 119 TFEU, 127(1) and (2) TFEU, as well as art. 17-24 of the Protocol on the ESCB and the ECB, on the one hand, because the ECB overstepped its mandate regulated in the aforementioned provisions concerning monetary policy and interfered with the competence of member states

62 P. Panfil, Polityka Europejskiego Banku Centralnego w dobie kryzysu [Policy of the European Central Bank at a time of crisis], at p. 11, available at: https://www.law. muni.cz/sborniky/dny_prava_2012/files/Verejnafinancnicinnost/PanfilPrzemyslaw.pdf (accessed 10.11. 2017).

63 T. Grosse, op. cit., at p. 117.

64 Peter Gauweiler and Others v Deutscher Bundestag, Case no 62/14, Judgment of 16.6.2015, ECLI:EU:C:2015:400. . 
and, on the other hand, because of the alleged non-compliance with art. 123 TFUE, which prohibits direct funding of the budget. ${ }^{65}$

With regard to the first issue, the Court of Justice at the beginning noted in general that the TFEU did not contain any specific definition of monetary policy and only laid down its objectives and means of its conducting by the ESCB. The Court of Justice rightly noted that "the ability of the ESCB to influence price developments by means of its monetary policy decisions in fact depends, to a great extent, on the transmission of the 'impulses' which the ESCB sends out across the money market to the various sectors of the economy. Consequently, if the monetary policy transmission mechanism is disrupted, that is likely to render the ESCB's decisions ineffective in a part of the euro area and, accordingly, to undermine the singleness of monetary policy. Moreover, since disruption of the transmission mechanism undermines the effectiveness of the measures adopted by the ESCB, that necessarily affects the ESCB's ability to guarantee price stability. (...)"66 The Court of Justice also emphasised that a monetary policy measure must not be treated as equivalent to an economic policy measure only because it may have indirect effects on the stability of the euro area. As a result, the Court of Justice considered the OMT programme as falling within the scope of monetary policy and did not identify any breach by the ECB of the scope of competence vested in the Bank by the Treaties (the Court also considered that the proportionality requirements had been taken into account).

With regard to the prohibition of direct funding of the member states by the European Central Bank and national central banks, the Court of Justice noted that art. 123(1) TFEU did "not preclude, generally, the possibility of the ESCB purchasing from the creditors of such a State, bonds previously issued by that State. (...) Nevertheless, the ESCB does not have authority to purchase government bonds on secondary markets under conditions which would, in practice, mean that its action has an effect equivalent to that of a direct purchase of government bonds from the public authorities and bodies of the Member States (...)." ${ }^{67}$ The Court of Justice considered at the same time that the OMT programme did not deprive the member states of an incentive to pursue balanced budgetary policies. Therefore, art. 123(1) TFEU does not prohibit the adoption and implementation

67 Gauweiler and Others v Deutscher Bundestag, at para. 95-97. 
of the programme, provided that the operations undertaken by the ESCB do not have the same effect as direct acquisition of government bonds from the member state bodies and public entities. Thus, eventually, the Court of Justice issued a judgement in favour of the ECB, stating that the relevant EU regulations (art. 119, art. 123(1) and art. 127(1) and (2) TFEU as well as art. 17-24 of the Protocol on the ESCB and the ECB) "must be interpreted as permitting the ESCB to adopt a programme for the purchase of government bonds on secondary markets, such as the programme announced in the press release." ${ }^{\prime 8}$

To move on to an evaluation of this judgement, it should be noted above all that the Court of Justice faced a difficult task of controlling the compliance of a secondary legislative act issued by the ECB with the treaty provisions. The economic and legal analysis made by the Court of Justice of the relevant regulations regarding monetary policy and the ECB's competence had the nature of a teleological interpretation and not a literal one. However, it may be justified with the rather general wording of the analysed treaty provisions. In this situation the Court is in a way forced to take into account the purpose of their introduction. A certain shortcoming of the judgement is the lack of an attempt to define what monetary policy is, or at least to indicate its typical instruments. Perhaps it was intentional, since the absence of clear-cut boundaries between monetary policy and economic policy allows "the ECB to 'test' new solutions without concerns about being unambiguously accused of overstepping its mandate set forth in the primary law, and grants to the Court a broader discretionary sphere in assessing such actions." ${ }^{69}$ The view is also voiced in the doctrine that the adoption of the OMT programme and recognition of its compliance with EU law by the Court lead to a change of the ECB's role - the likely scenario is that bond holders will consider the ECB as an entity with a function of a shadow lender of last resort. ${ }^{70}$

68 Gauweiler and Others v Deutscher Bundestag, at para. 127.

69 M.J. Nowakowski, Europejski Bank Centralny jako instytucja Unii Europejskiej, ze szczególnym uwzględnieniem jego funkcji wobec kryzysu strefy euro [European Central Bank as an EU institution, with special emphasizes on its functions towards the Eurozone crisis], Torun 2016, at p. 194, doctoral thesis prepared under the scholarly direction of Prof. dr hab. Jan Galster and dr Paulina Justyńska, available at the Main Library of the Nicolaus Copernicus University.

70 Cf. J. Jedrzejowska-Schiffauer, Judicial Dialogue on the ECB's OMT Decision: From Autopoetic Discourse to Legal Leveraging, "Studia Prawno-Ekonomiczne" 2016, vol. XCIX, at p. 58 and the literature referred to therein. 


\section{Changes to the scope of competence of the ECB introduced in the aftermath of the crisis and proposed}

The experience related to the crisis in the euro area prompted the introduction of a series of solutions which were designed to stabilise the euro area, whilst consolidating the ECB's position within the institutional system of the European Union. Those which affected the Bank to the greatest extent are linked above all to "the establishing of an integrated system of financial supervision in the EU and gradual building of the banking union. New responsibilities of the ECB also stem from the development of new mechanisms of financial assistance to the states threatened with a loss of financial stability." ${ }^{71}$

With regard to this latter area, first a temporary ${ }^{72}$ and subsequently a permanent mechanism of financial assistance was established the European Stability Mechanism. Its objective was to ensure financial stability within the euro area by safeguarding financial support for the states threatened with debt crisis. The establishing of the ESM entailed the need to make a limited amendment to the Treaty on the Functioning of the European Union (TFEU), which was processed in a simplified procedure. ${ }^{73}$ The mechanism itself was established on the basis of the Treaty establishing the European Stability Mechanism (ESM) ${ }^{74}$. It is worth stressing that its establishment was surrounded by certain doubt,

${ }^{71}$ M.A. Cichocki, Unia w Unii? Strefa euro w przebudowie [A union within the Union? The Eurozone under reconstruction], "Przegląd Natoliński" 2015, special issue no 2, at p. 83.

72 The European Financial Stabilisation Mechanism and the European Financial Stability Facility. Cf. For more details, see e.g. A. Wancio, op. cit., at pp. 48-49.

73 European Council Decision of the 2011/199/EU of 25 March 2011 amending art. 136 of the Treaty on the Functioning of the European Union with regard to a stability mechanism for Member States whose currency is the euro, O.J. L 91, 6.4.2011, p. 1-2. Paragraph 3, reading as follows: "The Member States whose currency is the euro may establish a stability mechanism to be activated if indispensable to safeguard the stability of the euro area as a whole. The granting of any required financial assistance under the mechanism will be made subject to strict conditionality" was added to art. 136 TFEU.

74 Treaty establishing the European Stability Mechanism, the text in English is available at: http://europa.eu/rapid/press-release_DOC-12-3_en.htm. The Treaty was originally signed by ministers of finance of the 17 euro area countries. Its modified version was finally signed on 2 February 2012 in Brussels. The ESM began to operate on 8 October 2012 after the Treaty was ratified by the 17 states of the euro area. 
including that regarding compliance with the Treaty of both the European Council Decision no. 2011/199, which amended art. 136 TFEU, and the new tasks entrusted within the framework of the Treaty to the EU institutions (the European Commission and the ECB). Another problem was determining whether the functions of the ESM fall within the monetary policy or rather economic policy conducted mainly by member states. Those doubts were resolved by the Court of Justice in its judgement of 27 November 2012 in the case Thomas Pringle $v$ Government of Ireland and Others. ${ }^{75}$ With reference to the first of the aforementioned issues, the Court stated, inter alia, that the European Council Decision no. 2011/199 did not extend the scope of competence vested in the Union in the treaties nor otherwise infringed the treaties, therefore, no grounds existed for considering the decision as invalid. In the context of the nature of the tasks of the European Stability Mechanism, the Court considered that the ESM activity did not fall within the scope of monetary policy, but "in the light of the objectives to be attained by the stability mechanism (...), the instruments provided in order to achieve those objectives and the close link between that mechanism, the provisions of the FEU Treaty relating to economic policy and the regulatory framework for strengthened economic governance of the Union, it must be concluded that the establishment of that mechanism falls within the area of economic policy." 76

With reference to the new tasks of the Commission and of the ECB under the mechanism, the Court of Justice pointed out that in accordance with the established jurisprudence, in the areas that are not within

75 Thomas Pringle v Government of Ireland and Others, Case 370/12, Judgment of 27.11.2012, ECLI:EU:C:2012:756.

76 Ibidem, para. 60. Further in the judgement, the Court of Justice also noted that "it is not the purpose of the ESM to maintain price stability, but rather to meet the financing requirements of ESM Members, namely Member States whose currency is the euro, who are experiencing or are threatened by severe financing problems, if indispensable to safeguard the financial stability of the euro area as a whole and of its Member States. To that end, the ESM is not entitled either to set the key interest rates for the euro area or to issue euro currency, while the financial assistance which the ESM grants must be entirely funded - the provisions of Article 123(1) TFEU being respected - from paid-in capital or by the issue of financial instruments, as provided for in Article 3 of the ESM Treaty. (...) any effect of the activities of the ESM on price stability is not such as to call into question that finding. Even if the activities of the ESM might influence the rate of inflation, such an influence would constitute only the indirect consequence of the economic policy measures adopted." - cf. Thomas Pringle v Government of Ireland and Others, paras 96-97. 
the exclusive competence of the Union the member states have the right to entrust the institutions with tasks beyond the remit of the Union, provided that these tasks are not contradictory with the nature of the powers vested in those institutions in the Treaties. The tasks of the Commission and of the ECB resulting from the Treaty establishing the ESM are analogous and include: assessing the urgency of requests for stability support (art. 4(4)), participating in the meetings of the Board of Governors and the Board of Directors as an observer (art. 5(3) and 6(2)), assessing, in cooperation of both institutions, of requests for stability support (art. 13(1)), negotiating an MoU detailing the conditionality attached to the financial assistance granted (art. 13(3)), and monitoring compliance with the conditionality attached to the financial assistance (Article 13(7)). ${ }^{77}$ The Court considered that the functions of both institutions were not contradictory with the nature of the tasks entrusted to them in the Treaties. It is beyond doubt, however, that they gain new powers with regard to granting financial assistance on request of the states covered with the European Stability Mechanism and thereby the ECB's mandate is extended, at least partially, to the sphere of economic policy.

The most significant changes in the ECB's functioning were introduced with the establishing of the integrated system of financial supervision in the EU. Within its framework, "the ECB took over the tasks in the area of microprudential supervision, that is supervision over individual deposit and credit institutions and other entities providing financial services in the euro area states and the states which do not participate in the currency union but decided to engage in the so-called close cooperation regarding the banking union. Furthermore, since 2015 the ECB has also participated in the decisions and measures taken by the newly established Single Resolution Mechanism for Restructuring and Orderly Liquidation of Banks." 78 The microprudential supervision exercised by the ECB includes: ensuring that the banks participating in the Single Supervisory Mechanism follow prudential standards, ensuring the correctness of the process of establishing and functioning of banks under this mechanism, undertaking investigative and controlling activities, as well as supervisory activities sensu stricto, related to the imposition on credit institutions of financial sanctions in

77 See Thomas Pringle v Government of Ireland and Others, paras. 156-157.

78 M.A. Cichocki, op. cit., at p. 84. 
accordance with regulation no 1024/2013 ${ }^{79}$. "Thus, in the European Banking Union, the ECB has the functions of the main body of microprudential supervision, and the national banking market supervisory authorities perform the tasks set by the ECB additionally (on a subsidiary basis)." In turn, macroprudential supervision exercised by the Bank encompasses measures taken in connection with the implementation of the provisions of directive no. $2013 / 36^{81}$, mainly its buffer provisions as well as undertaking activities and applying measures preventing the occurrence of a systemic risk and of macroprudential risks in the EU. ${ }^{82}$

Independently of those changes providing for new, important tasks for the ECB, proposals are presented concerning specification of its functions. For example, it is considered to be an oversight of the authors of the Treaties that the Bank has no mandate to maintain financial stability - therefore, the need to confer on the Bank competence in this respect is indicated. ${ }^{83}$ It is noted in the doctrine that "price stability and financial stability are therefore complementary objectives: without a smoothly functioning financial system, the transmission of monetary policy impulses is very difficult to attain; at the same time, stable price development is crucial for anchoring price expectations and price setting in the financial sector." ${ }^{84}$ Also the view that "it is time to develop a completely new approach for the ECB as lender of last resort" ${ }^{\prime 5}$ is expressed in the literature on the subject. An argument used here is, inter alia, the fact that the ECB has supervisory functions over the banks in the euro area, therefore, if any

79 Regulation No. 1024/2013 of 15 October 2013 conferring specific tasks on the European Central Bank concerning policies relating to the prudential supervision of credit institutions, O.J. L 287, 29.10.2013.

80 M. Fedorowicz, Nowe zadania ifunkcje Europejskiego Banku Centralnego w zapewnianiu stabilności finansowej w świetle regulacji Europejskiej Unii Bankowej [New tasks and functions of the European Central Bank in assuring financial stability in light of the European Banking Union regulation], “Zeszyty Natolińskie” 2016, no 62, at p. 39.

81 Directive of the European Parliament and of the Council No 2013/36/EU of 26 June 2013 on access to the activity of credit institutions and the prudential supervision of credit institutions and investment firms, amending Directive 2002/87/EC and repealing Directives 2006/48/EC and 2006/49/EC, O.J. L 176, 27.6.2013.

82 Ibidem, at p. 40.

83 M.J. Nowakowski, op. cit., at pp. 378-379.

84 G. Illing. P. König, The European Central Bank as Lender of Last Resort, "DIW Economic Bulletin" 2014, no 9, at p. 16.

85 K. Whelan, Banking Union and the ECB as Lender of Last Resort, UCD Centre for Economic Research Working Paper Series, WP16/09, August 2016, at p. 12. 
problems arise in their functioning, they should be considered as subject to joint responsibility of the ESCB. ${ }^{86}$ It is pointed out that the ECB has microprudential data concerning liquidity of the major banks in the euro area, therefore, a logical consequence should be the possibility to provide them with additional support - it seems all the more justified to regulate the ECB's role as a lender of the last resort. ${ }^{87}$

The question arises whether, in the context of all those changes introduced in order to enhance the role of the ECB in combating the financial crisis and the ones proposed for the future, a broader form of democratic control over the measures taken by the Bank should be provided for. A characteristic of the ECB is and must be its independence and that may not be questioned. However, at present the Bank is perceived as yet another bureaucratic institution within the European Union whose policy is incomprehensible not only to the EU citizens but in some cases also to EU member states themselves. Therefore, the proposed changes in the functioning of the ECB should also comprise certain forms of consolidating the Bank's legitimacy to act, in particular in crisis situations. Specialists put forward proposals of improving the Bank's image in a manner this is undertaken in the case of other institutions - that includes improved public communication and explaining more broadly to the general public the objectives of the anti-crisis actions pursued by the Bank. ${ }^{88}$ Another mechanism is economic dialogue - in the case of the ECB it would involve exchanging information and consulting economic policies with the European Parliament. ${ }^{89}$

\section{Final conclusions}

The analysis made in this article confirms that the European Central Bank played a vital role during the crisis, becoming at its critical moments the proverbial last hope. At the same time, its position both in the euro area and in the entire institutional system evolved significantly. This occurred not only in connection with the unconventional measures taken by the Bank,

86 Ibidem.

87 Cf. M.J. Nowakowski, op. cit., at p. 236.

88 For more details, see T. Grosse, op. cit., at p. 125 and the literature referred to therein.

89 Ibidem. 
but also as a result of the changes introduced by member states in order to overcome the crisis. In consequence, the Bank gained a series of new powers, including above all supervisory powers. Indeed, the crisis in the euro area confirmed that the ECB's competence set forth in the treaty regulations was not sufficient to take effective action in order to eliminate the negative effects of the crisis, and that the main objective of the European System of Central Banks should be to maintain not only price stability, but perhaps also financial stability. Having no appropriate financial and legal instruments in this regard, the ECB resorted to non-standard instruments such as longertime refinancing operations (LTRO), Securities Market Programme (SMP) and quantitative easing programme (QE).

Not all of them met with a positive reaction from member states and their central banks and from the economists assessing the effectiveness of those anti-crisis measures. Doubts also appeared regarding the overstepping by the ECB of its mandate granted to it in the treaty provisions, leading to proceedings before the Court of Justice in Luxembourg. However, the Court rejected allegations of this type, thereby paving the way for the application of subsequent non-standard instruments. This was probably dictated by the exceptional nature of the situation in which the ECC and the entire euro area found themselves. Consequently, both through the pursuit of its anti-crisis policy and as a result of the reforms implemented by member states in response to the crisis, the ECB consolidated its position. Its powers result not only from the treaty regulations, which essentially remained unchanged, ${ }^{90}$ but from a series of secondary legislative acts and international agreements concluded by member states outside primary law such as the Treaty establishing the European Stability Mechanism. Nevertheless, the increased competence of the ECB was not accompanied by actions aimed at strengthening the Bank's democratic legitimacy. Hence, at present, the change that should be introduced most commonly postulated in the literature is an increased scope of court control over the activities and democratic responsibility of the ECB.

\section{Bibliography}

1. Albiński P., Kryzysy i polityka stabilizacyjna w Unii Europejskiej [Crises and the stability policy in the European Union], [in:] Albiński P. (ed.), 'Kryzys

Except for art. 136 TFEU, to which paragraph 3 was added. See footnote 73. 
a polityka stabilizacyjna w Unii Europejskiej', Oficyna Wydawnicza SGH, Warszawa 2014

2. Bagus P., Tragedia euro, Ludwig von Mises Institute, Alabama 2012

3. Barcz J., Górka M., Wyrozumska A., Instytucje i prawo UE, $3^{\text {rd }}$ ed., LexisNexis, Warsaw 2012

4. Benedyk M., Polityka pieniężna Europejskiego Banku Centralnego w latach 1999-2013, "Ekonomia - Wrocław Economic Review” 2013, no 19

5. Białek N., Przyczyny wybuchu kryzysu strefy euro: rola polityki monetarnej USA oraz Europejskiego Banku Centralnego, "WSIiZ Working Paper Series" 2014, no 1

6. Cichocki M.A., Unia w Unii? Strefa euro w przebudowie, "Przegląd Natoliński" 2015, special issue no 2

7. $\quad$ Ciepłucha M., Zientalak E., Rola EBC $w$ walce z kryzysem strefy euro ze szczególnym uwzględnieniem kryzysu zadłużeniowego w Grecji, Wydział Ekonomiczno-Socjologiczny Uniwersytetu Łódzkiego, Łódź 2016

8. Claeys G., Leandro A., The European Central Bank's Quantitative Easing Programme: Limits and Risks, "Bruegel Policy Contribution" 2016, no 4

9. Cziomer E., Polityczno-prawne aspekty kryzysu zadłużenia strefy euro Unii Europejskiej, "Annales Universitatis Maria Curie-Skłodowska" 2012, vol. XIX

10. De Grauwe P., The European Central Bank as Lender of Last Resort in the Government Bond Markets, "CESifo Economic Studies" 2013, vol. 59, no 3

11. Eichler S., Financial crisis risk, ECB "non-standard"measures and the external value of the euro, "The Quarterly Review of Economics and Finance" 2012, vol. 52

12. European Central Bank, Monthly Bulletin. June 2010, Frankfurt am Main 2010

13. Europejski Bank Centralny, "Biuletyn Ekonomiczny. Przegląd sytuacji finansowo-gospodarczej" 2017, no 2

14. Fedorowicz M., Nowe zadania i funkcje Europejskiego Banku Centralnego $w$ zapewnianiu stabilności finansowej w świetle regulacji Europejskiej Unii Bankowej, “Zeszyty Natolińskie” 2016, no 62

15. Gronkiewicz-Waltz H., Europejska Unia Gospodarcza i Walutowa, LexisNexis, Warsaw 2010,

16. Grosse T., O trzech kryteriach oceny legitymacji Europejskiego Banku Centralnego w okresie kryzysu, "Myśl Ekonomiczna i Polityczna" 2013, no 2

17. Illing G.. König P., The European Central Bank as Lender of Last Resort, "DIW Economic Bulletin" 2014, no 9

18. Jedrzejowska-Schiffauer J., Judicial Dialogue on the ECB's OMT Decision: From Autopoetic Discourse to Legal Leveraging, "Studia Prawno-Ekonomiczne" 2016, vol. XCIX

19. Kil K., Ślusarczyk R., Dylematy polityki pieniężnej Europejskiego Banku Centralnego z perspektywy 2015 roku, [in:] Owsiak S. (ed.), 'Mechanizmy 
funkcjonowania strefy euro, wybrane problemy VI', Krakowska Szkoła Biznesu Uniwersytetu Ekonomicznego w Krakowie, Kraków 2015

20. Kozłowska J., Polityka Europejskiego Banku Centralnego w dobie kryzysu finansowego, "Zeszyty Naukowe Firma i Rynek" 2015, no 1

21. Kraciuk J., Kryzys finansowy strefy euro, "Optimum. Studia ekonomiczne" 2013, no 4,

22. Maliszewska-Nienartowicz J., System instytucjonalny i prawny Unii Europejskiej, Dom Organizatora, Torun 2010

23. Ministry of Finance, Kryzys grecki - geneza i konsekwencje. Dokument uzupetniajacy do ram strategicznych Narodowego Planu Wprowadzenia Euro, Warsaw 2010

24. NBP, Kryzys w strefie euro. Przyczyny, przebieg i perspektywy jego rozwiazania, Warsaw 2013

25. Nowakowski M.J., Europejski Bank Centralny jako instytucja Unii Europejskiej, ze szczególnym uwzględnieniem jego funkcji wobec kryzysu strefy euro, Torun 2016

26. Pronobis M., Czy Europejski Bank Centralny uratuje strefe euro?, "Analiza Natolińska" 2013, no 9

27. Scheller H.K., The European Central Bank. History, Role and Functions, Second revised edition, European Central Bank, Frankfurt am Main 2006

28. Sum K., Antykryzysowe działania Europejskiego Banku Centralnego - przyczyny, przebieg i skutki w poszczególnych fazach kryzysu "Zeszyty naukowe Wyższej Szkoły Bankowej we Wrocławiu" 2016, no 1

29. Szeląg K., Integracja walutowa w Europie Zachodniej w okresie powojennym, "Materiały i Studia" 2003, no 166

30. Wancio A., Europejskie Mechanizmy Stabilności Finansowe - gwarancja stabilności strefy euro czy gra na zwłokę?, "Wspólnoty Europejskie" 2011, no 3

31. Whelan K., Banking Union and the ECB as Lender of Last Resort, UCD Centre for Economic Research Working Paper Series, WP16/09, August 2016 